\title{
SOR JUANA INÉS DE LA CRUZ E KATE CHOPIN: LITERATURA DE RESISTÊNCIA EM SOCIEDADES MORALISTAS E REPRESSORAS
}

\section{SOR JUANA INÉS DE LA CRUZ E KATE CHOPIN: LITERATURE OF RESISTANCE IN MORALIST AND REPRESSIVE SOCIETIES}

\author{
Miquela Piaia' \\ [https://orcid.org/0000-0003-0555-5761] \\ DOI: 10.30612/raido.v14i35.10820
}

RESUMO: A presente artigo traz uma breve biografia sobre duas escritoras que abordaram nas linhas de suas obras importantes questionamentos sobre o papel da mulher dentro de sociedades nas quais as vozes femininas nâo costumavam ser ouvidas. A poeta barroca mexicana Sor Juana Inés de la Cruz (1651 - 1695) e a escritora norte-americana Kate Chopin (1851-1904) foram duas precursoras da literatura de conscientizaçâo feminina. Procuramos mostrar como as autoras transgridem várias regras sociais e históricas em termos de questóes de gênero no contexto de sociedades conservadoras - nas quais viviam. Como exemplo das suas escritas traremos o romance O Despertar (1899), no qual Chopin traça o desenvolvimento psicológico e sexual de uma jovem norte-americana em meio à comunidade creole de Nova Orleans. E Hombres Necios, poema de Juana Inés que faz uma crítica às sátiras que ridicularizavam as mulheres e eram muito comuns naquela época. Este trabalho aborda a contextualizaçāo literária, social, histórica e cultural das autoras, trazendo informaçōes sobre as suas relaçôes com o feminismo e, por fim, uma breve análise de suas obras sob a ótica feminista. É possível concluir que Juana Inés de la Cruz e Kate Chopin representam a vanguarda na luta pela eliminaçăo das discriminaçôes de gênero.

Palavras-chave: Juana Inés de la Cruz. Kate Chopin. Hombres Necios. O Despertar. Feminismo.

ABSTRACT: This article presents a brief biography of two writers who addressed in the lines of their works important questions about the role of women in societies in which female voices were not usually heard. The Mexican Baroque poet Sor Juana Inés de la Cruz (1651 - 1695) and the American writer Kate Chopin (1851-1904) were two pioneers of the women's awareness literature. We aim to show how the authors transgress several social and historical rules in terms of gender issues in the context of conservative societies - in which they lived. As examples of their writings, we will bring the novel The Awakening (1899), in which Chopin outlines the psychological and sexual development of a young American woman in the creole community of New Orleans. And Hombres Necios, a poem by Juana Inés which criticizes the satires that mocked women and were

Doutoranda em Letras pela Universidade de Passo Fundo.Possui Mestrado em Letras: área de concentraçáo Literatura pela URI - Universidade Regional Integrada do Alto Uruguai e das Missóes Campus Frederico Westphalen-RS. 
popular at that time. This paper addresses the literary, social, historical and cultural context of the authors, providing information about their relations with feminism and, finally, brings a brief analysis of their works from the feminist perspective. As a conclusion, we understand that Juana Inés de la Cruz and Kate Chopin represent the vanguard in the battle for the dismissal of gender discrimination.

Keywords: Juana Inés de la Cruz. Kate Chopin. Hombres Necios. The Awakening. Feminism.

\section{INTRODUÇÃO}

“Investigue o motivo que o manda escrever; examine se entende suas raízes pelos recantos mais profundos de sua alma; confesse a si mesmo: morreria, se lhe fosse vedado escrever?. Rainer Maria Rilke (Praga, 1875-1926)

Este trabalho apresenta a vida e obra de Sor Juana Inés de la Cruz, uma freira mexicana que viveu no período da Inquisiçăo e escreveu obras feministas e questionadoras de estética barroca. E da autora norte americana Kate Chopin, enfocando náo somente a questăo de gênero, mas também a forma como a escritora elabora uma crítica aos preceitos da época, através de uma linguagem que remete à coragem de uma mulher ao enfrentar uma sociedade machista na busca de seus desejos. Juana Inés de la Cruz e Kate Chopin estáo separadas na história por duzentos anos, a escritora mexicana nasceu em 1651 e a norte americana em 1851, e ambas trouxeram questóes de gênero nas suas obras que ainda persistem nos dias atuais.

Igreja, matrimônio e sociedade sâo instituiçôes poderosas, que instituem uma posiçăo quanto às suas respectivas responsabilidades no que concerne ao lugar e a condiçáo feminina - inferior e submissa. Era assim estabelecido que a mulher deveria louvar e reverenciar o sucesso de seu protetor, bem como submeter-se ao poder do seu provedor e da sociedade, pois só através deles será reconhecida, embora presa em uma teia de relaçóes de dependência material, existencial e emocional por ser obrigada a permanecer passiva e anônima. Esta dependência se materializa porque, para ser sujeito, a mulher precisava sujeitar-se às instituiçóes e ao sistema. A análise da vida e obra das escritoras nos direciona a reconhecer a vida como um processo onde o sucesso individual será medido pela capacidade de expressăo, pela possibilidade da mulher ser e perceber-se como sujeito.

O embasamento teórico deste trabalho é fundamentado em autores como Per Seyersted (1980), que discute a crítica feminina em relaçăo à literatura, Sandra Gilbert (1983), que discorre sobre feminismo, teoria e política, além de autores como Joyce Dyer (1993), Neal Wyatt (1995) e Harold Bloom (1987), que analisam, especificamente, a obra O Despertar. Quanto a vida e obra de Juana Inés de la Cruz utilizamos a pesquisa minuciosa sobre a freira mexicana realizada por Octavio Paz que resultou na obra Sor Juana Inés de la Cruz ou Armadilhas da fé (2017).

A pesquisa bibliográfica desenvolvida, apresentada em três partes, sendo que, na primeira seçăo, aborda-se a vida de Sor Juana Inés de La Cruz o e contexto histórico e social no qual ela viveu. Na segunda seçâo trazemos questōes relacionadas a questōes de gênero em seu poema Hombre Necios. A seçăo seguinte refere-se à vida, obra e 
crítica de Kate Chopin, que por uma tragédia familiar inicia sua vida literária e transforma-se em um símbolo de coragem e incentivo à constante batalha feminina em busca de igualdade e respeito. Na quarta seçâo analisamos a personagem feminina de O Despertar enfocando o despertar para a vida de Edna Pontellier e as consequências de suas atitudes, contrapondo regras sociais e direitos individuais. E por último sáo tecidas as consideraçóes finais.

\section{JUANA INÉS DE LA CRUZ: VIDA E OBRA}

Falar de Juana Inés, seja ela Sor Juana Inés de la Cruz, Juana Inés de Asbaje ou Juana Inés Ramírez, é falar de uma mulher revolucionária, com uma vida literária e uma história carregada de incertezas. Da mesma maneira, as certezas sobre Sor Juana săo poucas, mas poderosas. Desde jovem, a alma de Juana Inés nunca foi passiva, pelo contrário, era imparável e talvez o pior prejuízo à história da mexicana tenha sido a escassez de memórias.

As afirmaçōes relacionadas à vida de Sor Juana, três séculos depois de sua morte, ainda săo escassas, e văo desde sua exata data de nascimento, seu verdadeiro nome e filiaçăo. Conforme Paz (2017, p. 80), Guillermo Ramírez, parente distante de Sor Juana, e Enrique A. Cervantes, realizaram pesquisas e afirmam que a origem da freira data da Família Ramírez através de sua máe, Isabel Ramírez de Santillana, criolla nascida em Yecapixtla, na antiga Nova Espanha.

Desde muito cedo, a jovem Juana sempre esteve envolvida nos mais diversos questionamentos, o primeiro deles diz respeito a sua paternidade. Atribuída ao militar espanhol da província basca de Guipúzcoa, Pedro Manuel de Asbaje y Vargas Machuca, a quem Juana nunca conheceu. Desde seu nascimento surgiram dúvidas a respeito da veracidade da identidade paterna de Sor Juana. Além de viver em uma sociedade de homens para homens, a condiçâo de criolla năo a favorecia com relaçấo a credibilidade dentro da sociedade nova-espanhola, associada também ao fato de que o militar espanhol nunca se fez presente de forma ativa na criaçăo dos supostos filhos, sendo estes Juana e suas duas outras irmás.

Além disso, também foram encontrados registros datados de 1666, da Paróquia de Chimalhuacán, em Nepaltla, local de nascimento de Juana Inés, de certidōes de batismo assinadas por um frade denominado F. de Asvaje, sendo Asvaje uma suposiçăo ortográfica para o nome Asbaje, atribuído a Juana Inés. Trazendo mais suposiçóes para dentro da questăo, seria essa meramente uma coincidência histórica, talvez simplesmente um parente de Pedro Manuel, suposto pai de Inés ou a verdadeira identidade paterna de Sor Juana? As incertezas que assolaram a vida de Juana, se tornariam determinantes na criaçâo de sua imagem dentro da Corte e sociedade nova-espanhola de forma geral. Nascer mulher, criolla e de passado desconhecido em uma sociedade elitizada, machista e religiosa, foram fatores decisivos na criaçáo da persona de Sor Juana, o que viria a afetar sua vida e obra como será exemplificado posteriormente.

Em um período conturbado na história mexicana, na época chamada de ViceReinado da Nova Espanha, nasceu a futura poeta, no povoado novo-espanhol de San Miguel Nepantla, aos pés do vulcáo Popocatépetl, na segunda metade do século XVII. De acordo com Paz (2017, p. 80), o jesuíta Diego Calleja, em 1700, realizou um dos 
principais trabalhos sobre a história de Sor Juana, Fama y obras póstumas. Calleja afirma que a Fênix das Américas nasceu em 12 de novembro de 1651, entretanto até os dias atuais existem questionamentos e contradiçōes a respeito da teoria do jesuíta, sendo que, nunca foram encontrados nenhum tipo de documento histórico que comprove tal fato. Sabe-se que năo seria fácil encontrar tal documento, pois na época eram raros os registros de filhos naturais, com a filiaçăo parental aparente.

Com relaçâo à sua infância e juventude, pouco se sabe além de que, para Juana Inés, nem todo o conhecimento do mundo era suficiente. Mesmo nascendo em condiçấo de mulher, e por isso, năo tendo direito à educaçâo, Sor Juana nunca se deixou impedir o acesso ao conhecimento. A formaçấo intelectual de Juana foi inteiramente autodidata, quando criança, além do espanhol também aprendeu o náhuatl, idioma de origem asteca que era utilizado por nativos da regiăo onde morava. Mais tarde adquiriu uma fascinaçăo pela biblioteca de seu avô, onde se letrou também em latim e português além de estudar filosofia, ciência política e teologia. Com cerca de oito anos, Juana Inés foi mandada para a capital do território novo espanhol, a Cidade do México, para morar com os parentes María Ramirez, e seu marido Juan de Mata que a acolheram no centro político, religioso e cultural do mundo onde vivia. Juana Inés alcançou o conhecimento de tudo aquilo tido como verdade no mundo do século XVII em diversas perspectivas, deixando para trás as amarras sociais que lhe foram impostas.

Nâo se pode falar sobre a vida e obra de Sor Juana Inés de La Cruz sem falar do ViceReinado da Nova Espanha e da realidade do século XVII. Dentro da história mexicana, o período de três séculos que compreende a constituiçăo da Nova Espanha, é considerado um verdadeiro cativeiro da naçăo. A colonizaçăo da América Espanhola, iniciada com a chegada de Cristóváo Colombo às Antilhas em 1492, foi marcada pela exploraçáo de minérios como a prata e o ouro, além de desestruturar e por fim acabar com as antigas sociedades indígenas tradicionais da América constituídas nos Impérios Maia e Asteca. Após sua consolidaçăo, compreendia um vasto território desde a atual Califórnia, no litoral estadunidense até a Patagónia, nos territórios argentino e chileno. O território ainda, era dividido em quatro principais vice- reinados: Rio da Prata, Peru, Nova Granada e Nova Espanha.

O Vice-Reinado da Nova Espanha alcançou seu apogeu durante o século XVIII e tinha como símbolos a cruz, a espada e a coroa, acabando por se tornar uma fusăo do político, religioso e militar que se expandiram pelo território novo-espanhol através de conquista e evangelizaçâo. A sociedade nova-espanhola, demonstrava uma estrutura de classes que viria, em muito, se tornar fator decisivo na trajetória de Sor Juana Inés de la Cruz. Esta sociedade era composta, nos níveis mais altos, pelos espanhóis, nascidos da terra mâe e imigrantes na colônia, os quais detinham grande parte do poder político e econômico da época, seguidos pelos criollos, que eram uma classe de grande importância devido ao seu grande poder econômico, mas inferiores aos espanhóis de berço europeu. Por último na escala social, residiam os índios e negros, tanto nativos quanto escravos de terras além de oceanos.

No controle dessa complexa estrutura social estavam duas instituiçôes de exorbitante poder, e que por muitas vezes entraram em conflitos políticos e ideológicos. $\mathrm{Na}$ esfera política a ordem maioral era a Corte, coordenada pelo vice-rei de maneira unitária, já na esfera religiosa, esse papel era composto pela Igreja, com representaçấo do 
arcebispo. Ao longo da história mundial, conflitos políticos-religiosos entre o governo político e o teológico, foram comuns, e na Nova Espanha isso náo foi diferente.

Outro fator a ser considerado era o caráter machista da sociedade nova-espanhola do século XVII, a figura feminina na colônia, e em grande parte do mundo antigo, era limitada ao papel de submissa, sem direito à liberdade de pensamento, privadas de compreender o mundo onde viviam através do conhecimento. Uma sociedade estruturada por homens, năo abre brechas para mulheres conquistarem espaços, e foi exatamente isso que Juana Inés conseguiu fazer. O caráter libertário de Sor Juana, que defendia sua condiçâo como mulher intelectual e sua vocaçăo literária, a por isso, também tornara-se uma inimiga poderosa daqueles que ditavam as regras da colônia espanhola.

Tendo garantido fama por desafiar as instituiçōes governantes, em especial a Igreja, Juana Inés escreveu abertamente sobre suas paixóes, amores e opiniōes. Como exemplo disso podemos citar a Carta Atenagórica, na qual a poetisa mexicana expressou de forma vigorosa o seu descontentamento com relaçâo as opiniōes do Padre Antonio Vieira, o arcebispo novo-espanhol. A carta denominada Respuesta a Sor Philotea de la Cruz, de novembro de 1690, cria uma polêmica de razáo teológica envolvendo o pensamento de Sor Juana, que na condiçáo de freira náo poderia de maneira alguma expressar opiniōes, de concordância ou discordância, sobre a teologia.

Foi dentro dessas circunstâncias sociais, políticas e religiosas que se passa a história da escritora mexicana. E foi nesse contexto que Sor Juana Inés de la Cruz, na época ainda somente Juana Inés de Asbaje y Ramiréz, entrou para a elite social da Nova Espanha, ingressando como dama de companhia na Corte Vice-Real dos Marqueses de Mancera, na tenra idade de dezesseis anos. A mexicana foi admitida aos serviços da coroa com o título de "muito querida da senhora vice-rainha" segundo Diego Calleja (1700, apud PAZ, 2017). Deste momento em diante a fama e prestígio de Juana Inés começaram a aumentar de forma significativa. Suas obras caíram nas graças da vice-rainha Leonor Carreto, esposa do vice-rei Antonio Álvarez de Toledo e Salazar, e se popularizaram.

Tendo governado pelo período de 15 de outubro de 1664 à 20 de novembro de 1673, os Marqueses de Mancera foram a porta de entrada da obra do Sor Juana dentro da elite da Nova Espanha. O ingresso de Juana à Corte Vice-Real também está envolvido em questóes enigmáticas: como uma criolla, possivelmente bastarda, de passado incerto e nenhuma educaçăo formal foi aceita na Corte? Na época as cortes constituíam um polo de difusâo artística e o conhecimento era limitado a uma pequena parcela da elite populacional da colônia. A parte majoritária da populaçâo além de analfabeta, năo era aceita nos perímetros do palácio vice-real. Em uma sociedade como a de Sor Juana, o conhecimento foi sua chave de escape das condiçôes que a limitavam. Foi a integraçâo de Juana Inés na corte que possibilitou a ela construir uma rede de aliados políticos e eclesiásticos que seráo fundamentais em sua jornada.

Sor Juana, além de cumprir seus deveres com a Corte, também obteve a liberdade que almejava para se dedicar aos seus escritos, concretizou seu estilo de escrita de tamanha maestria e complexidade, como exaltavam os nobres espanhóis no século XVII, utilizando de sua paixăo e talento inegável, movida pela estética universalista do catolicismo barroco. Também fazia uso de estilos de fala popular das camadas mais baixas da populaçăo em suas obras, fazendo uso do vocabulário criollo e mestiço, assim como elementos até do próprio náhuatl na constituiçāo de suas obras. 
A relaçâo próxima de Juana Inés com a vice-rainha Leonor Carreto é atribuída como de natureza quase materna, demonstrado segundo Calleja (1700, apud PAZ, 2017, p . 110) que: "A senhora vice rainha náo podia viver um instante sem sua Juana Inés". Também relacionado ao fato de que a própria vice-rainha, conhecida como engenhosa, vivaz e altiva, era ainda, uma grande adoradora das letras. Paz (2017, p. 115), descreve a vice-rainha como "uma personalidade pouco comum, pois de outra forma náo se teria interessado tanto por Juana Inés nem a teria protegido de maneira tăo decidida", o que sinaliza que Leonor năo era uma mulher, tâo pouco uma rainha, convencional. Dentro dos próprios escritos de Sor Juana, a amizade com a vice-rainha é tratada como de uma natureza espiritual que demonstrada através de versos delicados a expressâo de uma amizade amorosa, e de gratidáo por aquela que a impulsionou no caminho das letras.

Por outro lado, o Marquês de Mancera, Antonio Álvarez de Toledo e Salazar, duvidou da capacidade intelectual de Juana Inés, antes de sucumbir ao fascínio pela jovem prodígio. Em conversa pessoal, retratada por Calleja (1700, apud PAZ, 2017 p. 124), cerca de cinco anos após a morte de Sor Juana, o antigo vice-rei revela que:

[...] quis averiguar se essa sabedoria tăo admirável era infusa ou adquirida ou artifício ou náo natural, e reuniu em um dia em seu palácio quantos homens professaram letras na Universidade e na Cidade do México. O número de todos chegaria a quarenta e nas profissôes eram vários, como teólogos, escrivăes, filósofos, matemáticos, historiadores, poetas, humanistas [...] que à maneira de um galeáo real - traslado as palavras de Sua Excelência - se defenderia de alguns barquinhos que sobre ela investiram, assim se desembaraçava Juana Inés das perguntas, argumentos e réplicas que tantos, cada um em sua classe, lhe propuseram.

Confirmando assim, a magnitude do conhecimento vivo que representava Sor Juana, que fez o próprio Marquês render-se aos seus encantos intelectuais.

Foi também na estadia enquanto dama de companhia dos Marqueses de Mancera que Juana Inés conheceu o jesuíta Antonio Núńes de Miranda, criollo e de origem familiar de clérigos e militares. Figura pública e amplamente respeitada, principalmente por suas atuaçóes como reitor do Colégio de San Pedro y San Pablo, provincial da Companhia de Jesus e qualificador do Santo Ofício. Núñes também se tornou confessor dos Marqueses de Mancera, momento no qual conheceu Juana Inés, vindo, posteriormente, também a se tornar confessor da mexicana, acompanhando-a em grande parte da vida.

A estadia de Sor Juana na corte dos marqueses de Mancera durou cerca de quatro anos, passando dos seus dezesseis aos vinte anos, na transiçăo de menina para mulher. Os anos de Inés na corte, segundo indícios presentes nos primeiros trabalhos da autora, foram repletos de esplendor e arte, festas e bailes, saraus e comédias, retratados nas palavras da poetisa com tom de experiência.

Os fatos descritos anteriormente tornam os acontecimentos seguintes da vida de Sor Juana misteriosos: ainda aos dezenove anos ela se junta a Ordem San José de las Carmelitas Descalzas, vestindo o hábito ao se tornar uma noviça, permanecendo na Ordem por apenas três meses. Sáo enigmáticos os motivos que levaram Juana Inés no auge de seu reconhecimento na corte, ainda jovem e bela, a tomar a decisáo de vestir o hábito. Juana precocemente desliga da Ordem, atitude atribuída às doutrinas severas e pouca liberdade para a expressăo de pensamentos de cunho năo inteiramente religiosos. Juana Inés entăo vai para a Ordem de San Jerónimo, onde viria oficialmente a tornar-se Sor (Freira) Juana Inés de la Cruz. 
Em 24 de fevereiro de 1669 Juana Inés abdicava do próprio nome para se tornar uma noviça Jerónima, uma verdadeira esposa de Cristo, na ordem conhecida por sua brandura disciplinar. Ainda que as dúvidas sobre sua decisăo perdurem, as razôes por trás de sua escolha podem ter sido associadas à influência de seu confessor, Padre Núñes de Miranda, mas principalmente à concepçăo de que somente o voto de clausura enquanto freira, traria o espaço e a liberdade que ela almejava para dedicar-se aos estudos. Outras hipóteses foram levantadas ao longo dos séculos: seria uma decepçâo com um amor impossível talvez devido à sua condiçáo de criolla, ou ao abandono, ou ainda, a fuga de sentimentos que a distanciavam da condiçâo heterossexual?

Ainda que, grande parte dos pensadores católicos que já discursaram sobre Sor Juana, defenda a hipótese de que ela ingressou na vida religiosa por pura devoçấo ao chamado de Deus, é importante ressaltar que para grande parte daquelas que vestiam o hábito, a vida religiosa era apenas uma ocupaçâo. As Igrejas e principalmente os Conventos eram além de instituiçóes poderosas diante da realidade da colônia, uma válvula de escape para a realidade mundana, muitos procuravam a vida religiosa como uma fuga ao matrimônio indesejado ou até mesmo como uma maneira de garantir sustento econômico. A própria Ordem de San Jerónimo era tratada como uma alternativa para se fugir das dificuldades econômicas e sociais, porém năo atingia a todos, para o ingresso na vida monástica era necessário um dote e um nome de família tradicional.

O ingresso de Sor Juana na Ordem de San Jerónimo teve grande influência dos Marqueses de Mancera, pois a jovem Juana Inés sozinha, sem nome conhecido e amparo de familiares, jamais teria chegado a ingressar na Ordem. É provável que a conexâo entre Juana Inés e Pedro Velázquez de la Cadena, nobre espanhol que se tornou o financiador de seu dote, tenha sido organizada pelas máos da vice-rainha Leonor e de seu guia espiritual o Padre Núnes de Miranda.

É bastante provável que Sor Juana optou pela vida monástica dentro da busca por segurança como já mencionado, sua única casa era o palácio e ali ela sabia que nâo teria estabilidade para sempre, os vice-reinados năo eram de grande duraçăo, logo os Marqueses iriam ser mandados de volta para seu país natal e Juana nâo seria mais protegida da coroa. Outro ponto a se destacar é a inflûencia de Padre Núñes, que já era conhecido como frequentador dos mais diversos conventos, nos quais fora diretor e guia espiritual de diversas freiras.

Mesmo durante a vida monástica, Juana Inés manteve características que já demonstrava dentro da corte dos Marqueses de Mancera. Era conhecida por sua sagacidade, beleza transmitida através das palavras e desejo pelo saber, e nâo por sua devoçăo. Durante os vinte e seis anos que permaneceu na Ordem Jerónima, essas características năo mudaram. Mesmo sendo evidente em seus escritos que era uma católica devota, a expressáo de voz pessoal de Sor Juana falava mais alto que seu amor por viver em serviço do Senhor. A icônica Respuesta a Sor Philotea de la Cruz, de novembro de 1690, reforça a posiçăo de Juana Inés, que além de religiosa também era politizada. Ressaltando o escândalo provocado pelas palavras de Sor Juana, que além de năo tradicionais diretamente com as de outro religioso amplamente conhecido, o jesuíta português Antonio Vieira. O que acabou por colocar Juana Inés em uma posiçâo complicada com relaçâo a sua posiçăo como religiosa, vide que, o pouco que escrevia sobre fatos de ordem religiosa era controverso, demonstrando que sua devoçáo năo era tăo incontestável assim. 
A realidade presente dentro da vida monástica de Sor Juana foi repleta de práticas que favoreceram as criaçóes da poetisa. As monjas eram proibidas de sair fisicamente para ter contato com o mundo exterior pelo voto de clausura, porém os conventos eram palco para visitas ilustres de teólogos, clérigos e outras figuras de cunho religioso, até damas e senhores da corte, principalmente vice-reis e vice-rainhas. Também eram realizadas festas e celebraçôes, peças teatrais e saraus, tornando várias figuras conhecidas na história assíduas na Ordem Jerónima, como o próprio frei García Guerra, arcebispo do México. Essas práticas e postura aberta das Ordens ainda que promovessem os conventos como centros de disseminaçăo cultural, também violavam os votos das esposas de Cristo em vários quesitos, essas condutas trouxeram a Sor Juana e a toda a Ordem Jerónima uma aliada e um inimigo poderoso, a vice-rainha María Luisa Manrique de Lara y Gonzaga, a condessa de Paredes de Nava e o temido arcebispo Francisco de Aguiar y Seijas.

Quando Juana Inés estava com vinte e seis anos, o Frei Payo foi nomeado vice-rei, nessa época a freira lamentava a morte de sua antiga protetora, Leonor Carreto. 0 governo de Payo durou até Juana Inés chegar aos seus trinta e um anos, foi um período pacífico de relaçôes cordiais com a Ordem Jerónima e a populaçăo criolla. Depois desse governo, quem assumiu o cargo de vice-rei foi Dom Tomás Antonio de la Cerda, Marquês de la Laguna, primo de Frei Payo, e sua esposa a vice-rainha María Luisa Manrique de Lara y Gonzaga, condessa de Paredes de Nava. Se no governo dos Marqueses de Macera a vida e obra de Sor Juana ganharam reconhecimento, no dos Marqueses de la Laguna elas chegaram a seu apogeu.

Em termos políticos e sociais o governo dos Marqueses de la Laguna foi conflituoso, assolado por lutas indígenas e saques à costa nova-espanhola. Apesar de o governo de Dom Tomás ter deixado a desejar em inúmeros aspectos, foi o período mais pleno e promissor da história de Sor Juana. As visitas abertas à Ordem de San Jerónimo e a elaboraçăo do Arco Triunfal, monumento efêmero erigido durante as grandes celebraçóes públicas barrocas, para a chegada da corte, possibilitaram a aproximaçâo de Sor Juana e da Condessa de Paredes. María Luisa, tratada por Sor Juana como Lysi, era descrita como belíssima e de enorme esplendor como podemos ver no trecho "la belleza de María es Mar que se lleva a los ojos"2(PAZ, 2017, p. 195).

Foi durante o governo de Tomás de la Cerda, que Juana Inés escreveu o seu maior número de obras, sendo quase todas dedicadas ao próprio vice-rei, a sua esposa María Luisa e ao filho do casal. Segundo Paz (2017) a escrita mexicana produziu 216 poemas, destes 52 dedicados somente aos Marqueses de la Laguna. Sendo importante ressaltar que a poesia barroca dirige ao leitor esquemas de arquétipos do amor e das paixóes, mas o leitor năo deve inferir a estes um valor confessional, năo é de característica do período. Os poemas de Sor Juana demonstram isso, a escritora utiliza elementos etéreos, religiosos, sarcásticos e lógicos que discorrem sobre o amor e suas singularidades, expressas nos versos dedicados principalmente a Condessa de Paredes.

Além de sua funçâo cortesă, a poesia dedicada aos superiores geralmente compreendia um propósito de característica humilde, de comoçâo e adoraçâo. Sor Juana por outro lado, apresentava poesias de cunho menos humilde e mais estético apelando

"A beleza de María é Mar que se leva aos olhos" (PAZ, 2017. p. 195) 
para as graças, demonstrando uma relaçăo que exalava privilégios seus com relaçăo a coroa nova-espanhola.

Esses elementos característicos nas obras de Juana Inés levantam a hipótese de um possível relacionamento amoroso com a Condessa de Paredes de Nava, María Luisa Manrique de Lara y Gonzaga. Essa possibilidade afasta Juana Inés da característica assexual imposta por sua vida monástica e da característica heterossexual socialmente aceita na sociedade nova-espanhola. Sendo importante ressaltar que a liberdade sexual imposta na Nova Espanha era, por vezes, bem mais branda que a religiosa, entretanto isso se aplicava a populaçăo civil, nâo aos que prosseguiram uma vida religiosa. $O$ despertar sexual de Sor Juana com relaçăo à María Luisa, ainda que por vezes explícito por meio dos versos dedicados à Lysi, foi uma questăo obscurecida pela censura da época. Muitos de seus manuscritos e correspondências foram ocultados devido a necessidade de se apagar da história esse possível escândalo que mancharia a imagem da Igreja.

Ainda que o teor do relacionamento de Sor Juana e da Condessa de Paredes de Nava seja incerto, năo podemos descartar a notoriedade do papel que María Luisa desempenhou para a disseminaçấo da obra de Juana Inés. Segundo Paz (2017), a condessa de Paredes levara à Espanha os manuscritos da amiga e é quase certo que ela tenha bancado a impressăo: o livro era uma homenagem a sua pessoa e à casa dos Laguna, exemplificando assim, o papel importantíssimo da Condessa, na publicaçâo das obras de Sor Juana. Maria Luisa continuou a apoiar e trocar correspondências com Sor Juana mesmo depois do fim de seu reinado.

A poesia de Sor Juana é caracterizada pelo subjetivismo, ou seja, uma reflexáo profunda sobre seu eu que muda de forma e assume papeis năo vividos oficialmente por Sor Juana, classe e gênero, sendo por vezes mulher livre de classe alta, as vezes noiva, as vezes viúva, mas nunca faz alusâo ao seu estado religioso, em nenhum momento se coloca como freira. Esses poemas escandalizaram o Arcebispo Francisco de Aguiar y Seijas, outra figura importante que cruzou o caminho de Sor Juana, que era notoriamente conhecido pelo seu desprezo a tudo que era considerado feminino, o corpo, as características ou até mesmo a presença.

A história de Juana Inés com a religiosidade é controversa, a figura de Sor Juana Inés de la Cruz se afastava da vida monástica em muitos aspectos. Sor Juana defendia sua liberdade criativa, e sua avidez pela comunicaçâo escrita revela também em partes um anseio pelo conhecimento. A imagem de Sor Juana sempre foi rodeada de questōes que ultrapassavam o âmbito religioso e isso se tornava explícito em suas açôes. Das inúmeras discussóes com seu confessor, Padre Núnes de Miranda, ao desapreço vindo do Arcebispo Aguiar y Seijas, até a elaboraçăo da Carta Atenagórica, Juana sempre se fez ouvida. A Carta é um dos trabalhos mais conhecidos e discutidos de Sor Juana.

Publicada nos últimos dias de novembro de 1690, a Carta é uma crítica ao Sermâo do Mandato do jesuíta português Antonio Vieira. Vieira é uma figura ilustre na história, considerado um dos grandes pensadores do século com diversos escritos famosos, o mesmo atuou fortemente durante a colonizaçâo portuguesa no Brasil. A Carta dirige-se à um destinatário que permanece incógnito e foi escrita com muita sutileza, que traz o leitor para uma sensaçâo de círculo íntimo onde serâo depositadas as suas palavras

Os últimos anos de vida de Sor Juana foram, talvez, os mais intrigantes. A vida da poetisa que foi repleta de incertezas, neste momento năo foi diferente. Em cinco de 
março de 1694 Sor Juana Inés de la Cruz assina um documento que viria por definir os seus últimos anos de vida, renunciando supostamente o estudo das letras com fins de se dedicar à vida monástica. Esse acontecimento marca o fim da trajetória de Juana Inés como poeta e figura ilustre dentro da sociedade nova espanhola.

É nesse contexto que se concretizam os dois últimos anos de Juana Inés. Entregue aos votos de clausura, obediência, castidade e pobreza, Inés abdicou do ato de escrever e de seus bens materiais, em especial a biblioteca com mais de três mil volumes que mantinha dentro de sua cela no Ordem Jerónima, além de instrumentos musicais e científicos a fim de vendê-los arrecadando dinheiro para os mais necessitados. A posiçáo de Sor Juana, foi considerada sublime por seus contemporâneos, demonstrando uma rendiçăo por parte da freira que representava naquele momento ser uma mulher que buscava rendiçăo e proteçăo.

Os atos anteriores à renúncia de Sor Juana, em especial a Respuesta, colocaram a freira em uma posiçáo contraditórias as ideologias da Igreja, que causaram desapreço especialemente do Arcebispo Aguiar y Seijas. É possível que naquele momento, Juana sabia que se encontrava sem apoio e buscava uma maneira de garantir sua segurança. Hoje sabemos que mesmo o voto de renúncia năo impediu Sor Juana de prosseguir exercitando sua capacidade intelectual, a mesma se manteve dedicada à estudos e pequenas escritas até mesmo nesses últimos anos, um adendo à sua perseverança e rebeldia.

Conforme Paz (2017, p. 544), em meados de abril de 1695, uma epidemia desconhecida chegara ao convento de San Jerónimo, descrito pelo presbítero Cayetano de Cabrera y Quintero, como matlazahuatl (em náuatle: rede de furúnculos ou pústulas) foi uma epidemia até hoje nâo identificada, provavelmente causada por uma bactéria em mutaçăo fruto das mutaçóes biológicas advindas do choque do Novo com o Velho Mundo) trazendo o fantasma da morte para o cotidiano novo espanhol. Estima-se que dentro do convento, uma à cada dez freiras que se fazia doente, sobrevivia. Nesse momento Sor Juana demonstrou suas habilidades como cuidadora caridosa, temendo por suas irmás em leito de morte até 17 de abril, quando aos quarenta e seis anos, ela mesma caiu nas desgraças dessa peste náo identificada.

\section{JUANA INÉS E O FEMINISMO}

Uma mulher realmente muito à frente de seu tempo, Sor Juana Inés de la Cruz foi um importante ícone feminista, uma das maiores precursoras do feminismo latino americano, nasceu em um contexto histórico que reconhecia a mulher como objeto de posse à um senhor superior, pai, marido ou até a própria divindade representada por Deus. Juana Inés caminhou a terra séculos antes do feminismo se tornar pauta na América Latina, e ainda assim, representa um papel importantíssimo na formaçâo da mulher enquanto ser pensante e atuante diante do mundo que as cerca.

A iniciativa dada como feminista de Juana Inés começa na infância com seu desejo insaciável pelo conhecimento, principalmente aquele proibido para "seres inferiores" tais como as mulheres. Mais tarde, a jovem Juana viria a trilhar um caminho repleto de rebeldia, que marcaria o seu lugar como uma figura controversa e de esplêndida relevância. Năo podemos tratar das características feministas de Sor Juana sem tratar da repressâo e machismo vindos da sociedade nova espanhola. Na Nova 
Espanha e muitos lugares do mundo as mulheres eram consideradas seres fracos, intelectualmente inferiores, verdadeiras posses. Sor Juana encontrou uma maneira de contornar a situaçấo através da veste do hábito. O ingresso enquanto freira jerónima proporcionou a Inés a liberdade necessária para que pudesse proferir seus dons de escritora enquanto defendia sua liberdade individual para tratar daquilo que bem lhe interessava.

Outro fator chave no entendimento de Sor Juana enquanto agente precursora feminista, é masculinizaçăo da figura da poetisa. É natural que a imagem de uma mulher que dominava com tamanha maestria um campo inteiramente masculino, como era o caso das letras, seja distorcida.

A avidez de Sor Juana pela comunicaçâo escrita revela consigo características que uma mulher da época, muito mais ainda uma confinada na vida monástica, o oportunismo, o narcisismos e fome de poder. Juana nâo poupava os argumentos à seu favor por meio de sua poesia rítmica e manipuladora. Para encaixar-se nesse meio, até a própria Juana precisou se desvincular dos estereótipos femininos e concentrar a si em uma tarefa que anteriormente à ela, nâo lhe dava o devido espaço.

\subsection{Hombre Necios}

Expressos nos versos da Carta Atenagórica e em Hombres Necios, o desapreço de Juana Inés pelas práticas restritivas da Corte assim como da própria Igreja, se fez claro sem mais espaço para manifestaçōes. Dentro dos dois supracitados, o segundo, em especial, tem grande relaçấo com à figura de Sor Juana e sua imagem de si mesma. Suas diversas representaçōes em meio à seus escritos, a de máe, esposa e cuidadora, sáo previamente abandonados dentro do poema que soa mais como um desabafo necessário diante das práticas que suportavam ela e suas irmăs.

A relaçâo de Sor Juana Inés de la Cruz com o feminismo está presente em suas obras, que sâo repletas de questionamentos e denúncias sociais e ideológicas. Em Hombres Necios, a freira, poetisa e intelectual faz uma crítica a postura masculina em relaçâo as mulheres. Conforme Taveira (2017, p. 75):

Num período em que o acesso à escrita era difícil para a populaçáo geral e raro para as mulheres, Juana Inés desenvolve uma poesia liberta e pronta para combater as indiferenças de gênero bem como assegurar a presença do amor autônomo, independente do gênero ou da condiçấo social dos envolvidos. Num período em que o ensino superior estava proibido para as mulheres, a monja mexicana provou que era possível adentrar num mundo, a priori cercado dos costumes masculinos, e deslizar entre a corte e a igreja para desmistificar crenças introduzindo o poder de fala da mulher até entăo irrelevante.

Vejamos a seguir o poema em questăo, escrito por Juana Inés no século XVII: 
Hombre necios ${ }^{3}$

Arguye de inconsecuentes el gusto y la censura de los hombres que en las mujeres acusan lo enduravam que causan

Hombres necios que acusáis

a la mujer sin razón,

sin ver que sois la ocasión

de lo mismo que culpáis:

si con ansia sin igual

solicitáis su desdén,

¿por qué queréis que obren bien

si las incitáis al mal?

Combatís su resistencia,

y luego, con gravedad,

decís que fue liviandad

lo que hizo la diligencia.

Parecer quiere el denuedo

de vuestro parecer loco,

al niño que pone el coco

y luego le tiene miedo.

Queréis con presunción necia,

hallar a la que buscáis,

para pretendida, Thais,

y en la posesión, Lucrecia.

¿Qué humor puede ser más raro

que el que, falto de consejo,

él mismo empaña el espejo

y siente que no esté claro?

Con el favor y el desdén

tenéis condición igual,

3 Homens néscios - Argúi ser inconsequência o gosto e a censura dos homens, que às mulheres acusam do que eles causam. Homens néscios a acusar/às mulheres sem razâo,/ sem ver que sấo a ocasiâo/do que as estâo a culpar./Se com ânsia sem igual/ estimulam seu desdém,/ por que querem que obrem bem/se as incitam para o mal? / Combatem sua resistência,/ e em seguida com maldade/ dizem que foi leviandade/ o que fez sua insistência./ Querem com vil presunçâo/ achar a que lhes condiz:/ em compromisso, Taís,/ e Lucrécia em possessăo./ Que humor pode ser mais raro/ que o que recusa um conselho? / O mesmo que encobre o espelho/ diz que năo lhe está bem claro./ Com o favor ou o desdém/ o resultado é igual:/ se queixam, se os tratam mal;/ enganam, se os querem bem./ Opiniăo nenhuma ganha,/ pois a que mais se recata,/ se năo lhes aceita, é ingrata,/ e, se aceita, é piranha./Sempre tâo tolos a andar/ com seu discurso fiel,/ a uma a chamar de cruel/ e a outra de fácil chamar./ Como talvez se interesse/ a que seu amor pretende,/ se à que é ingrata ofende/ e à que é fácil aborrece?/ Mas entre o aborrecimento/ e a pena, de seu deleite,/também há quem os rejeite/ e que os deixe em bom momento./Às amantes que mantêm/lhes dâo asas sem domá-las,/ e após mal acostumá-las/querem encontrá-las bem./ Maior culpa terá havido,/ em uma paixăo errada,/ aquela que cai prostrada/ ou o que se prostra caído?/ Qual é mais de se culpar,/ ainda que ambos seu mal tragam:/ a que peca porque pagam/ ou o que paga por pecar?/ Entăo para que espantar-se/ pela culpa que náo têm?/Queiram a que lhes convém/ ou convenham para amar-se./ Parem de tanto insistir/ e depois com mais razâo/ à atitude acusarâo/ da que entăo os seduzir./ Com muitas armas ao fundo/ luta sua prepotência,/ pois em promessa e insistência/ juntam diabo, carne e mundo. (Traduçăo: Anderson Braga Horta, 2000). 
quejándoos, si os tratan mal,

burlándoos, si os quieren bien.

Opinión, ninguna gana;

pues la que más se recata,

si no os admite, es ingrata,

y si os admite, es liviana.

Siempre tan necios andáis que, con desigual nivel,

a una culpáis por cruel

y a otra por fácil culpáis.

¿Pues cómo ha de estar templada

la que vuestro amor pretende,

si la que es ingrata, ofende

y la que es fácil, enfada?

Mas entre el enfado y pena

que vuestro gusto refiere,

bien haya la que no os quiere

y quejáos en hora buena.

Dan vuestras amantes penas a sus libertades alas, y después de hacerlas malas las queréis hallar muy buenas.

¿Cuál mayor culpa ha tenido en una pasión errada:

la que cae de rogada,

o el que ruega de caído?

¿O cuál es más de culpar, aunque cualquiera mal haga:

la que peca por la paga,

o el que paga por pecar?

Pues ¿para qué os espantáis de la culpa que tenéis?

Queredlas cual las hacéis

o hacedlas cual las buscáis.

Dejad de solicitar

y después, con más razón,

a cusaréis la afición

de la que os fuere a rogar.

Bien con muchas armas fundo que lidia vuestra arrogancia, pues en promesa e instancia juntáis diablo, carne y mundo. 
Podemos ver nas linhas do poema o panorama social da Nova Espanha do século XVII, e a forma repressora e moralista imposta às mulheres. Ao longo de uma apóstrofe e dezessete estrofes Juana Inés faz uma crítica severa e direta as sátiras que ridicularizavam as mulheres e eram muito comuns naquela época. A escritora enfatiza sua discordância em relaçăo a conduta masculina em relaçáo ao gênero feminino, especialmente nas seis perguntas que dirige aos homens ao longo do poema.

\section{KATE CHOPIN: VIDA, OBRA E CRÍTICA}

Kate Chopin nasceu Katherine O'Flaherty no dia 8 de fevereiro de 1850, descendente de irlandeses e franceses, em St. Louis, Missouri. A jovem Kate foi agraciada por ter muitas mentoras mulheres ao longo de sua infância e também viúvas fortes e independentes em sua família, além das freiras intelectuais em sua escola, que a ensinaram viver a vida da mente como a vida do lar. Kate tinha cinco anos e meio quando seus pais lhe mandaram para a Academia do Sagrado Coraçâo. Seu pai, Thomas O'Flaherty, era um imigrante irlandês de muito sucesso nos negócios. Em $1^{\circ}$ de novembro de 1855 , como um dos fundadores da estrada de ferro do Pacífico, seu pai estava a bordo do trem em sua viagem inaugural sobre a ponte Gasconade, que entrou em colapso, matando muitos dos passageiros. Apenas dois meses após ter entrado na Academia Sagrado Coraçăo, Kate voltou para casa e, a partir de entăo, foi educada por sua bisavó. Eliza Faris O'Flaherty, sua máe, era membro da proeminente comunidade Franco-creole e de um exclusivo círculo social. Eliza tinha apenas 27 anos quando soube da morte de seu marido, entăo com 50 anos de idade. Deveria ter ficado deprimida pela notícia ou, como Kate Chopin sugere em sua História de Uma Hora (2011), "uma esposa, ao ouvir que seu marido morre em um acidente de trem, delicia-se em pensamentos de liberdade". Sua máe mal tinha 16 anos quando casou-se com Thomas O'Flaherty - seis meses depois que sua primeira esposa havia morrido, deixando-o com um filho, George. Eliza trouxe consigo certo status social para o casamento, ela que era a mais velha de uma empobrecida, mas bem estabelecida família de sete irmáos. Thomas, um homem independente, trouxe dinheiro à uniâo. Eliza nunca se casou novamente após a morte do marido. A avó e a bisavó de Kate também enviuvaram com pouca idade e năo mais casaram-se. Eles eram tios e tias jovens, primos e quatro escravos na casa, mas, individualmente, as mais fortes eram as viúvas. Os tataravós de Kate protagonizaram o primeiro divórcio legal lavrado em St. Louis. Sua tataravó aprendeu entâo a ler e a escrever, deu à luz um bebê cujo pai desconhece-se o nome, tornou-se empreendedora do ramo da navegaçâo e, assim, magnata do século XVIII. Kate, tendo perdido duas importantes figuras masculinas ainda cedo, desenvolveu fortes laços com sua bisavó. A avó de Kate, Madame Charleville, deu à luz quinze filhos de seu marido mercante Joseph Charleville. Conforme Seyersted (1980, p. 149), a bisavó ensinou Kate năo apenas música, história e o idioma francês, mas também a viver a vida de forma livre e despida de medo.

Dois anos após a morte de seu pai, Kate voltou à Academia do Sagrado Coraçăo. Como interna no convento ela experimentou as restriçôes de uma educaçăo católica. Kate encontrou uma menina chamada Kitty Garesche, e as duas garotas adoravam escrever e ler juntas, segundo Seyersted (1980, p. 21). Em maio de 1861 a Guerra Civil eclodiu em St. Louis e a família de Kitty foi banida por suas inclinaçōes junto aos confederados. Kate năo apenas perdeu sua melhor amiga, mas também o meio irmăo, George, que 
morreu de febre tifoide. Kate perdeu todos os seus irmăos e irmăs, tendo entăo 24 anos quando tornou-se "filha única". Quando formou-se na Academia do Sagrado Coraçăo, Kate era conhecida como uma brilhante escritora, estudante honrosa, jovem crítica e pianista de talento. Depois da guerra ela quase entrou em depressăo e uma das freiras da academia reconheceu a criatividade da jovem solitária. A freira autorizou-a a escrever um livro de trivialidades, que é o primeiro escrito por Kate. Este livro tornou-se um diário de sua vida social e intelectual.

Quando tinha 19 anos, Kate conheceu Oscar Chopin, nativo da Louisiana e produtor de algodăo, e casou-se com ele em 9 de junho de 1870. Os últimos trechos de seu livro de amenidades sấo o diário de sua lua-de-mel de três meses pela Europa. Como era típico das mulheres de sua época, ela năo mencionou aspectos sexuais deste período, ainda que recorde a consumaçâo de seu casamento em 12 de junho na Filadélfía. O casal estabeleceu-se em Nova Orleans enquanto aguardava o nascimento de seu primeiro filho, presumidamente concebido durante o período na Europa. Quando os negócios de Oscar faliram em 1879, ele decidiu que deveriam mudar-se para o norte, para as plantaçóes de sua família na localidade de Natchitoches Parish, e foi entăo que Kate tornou-se membro da Comunidade Creole, que tornou-se foco importante de seus escritos. Em 1882, Oscar contraiu febre do pântano e morreu por complicaçóes da doença em janeiro de 1883. Entăo Kate voltou a St. Louis com seus seis filhos. Um ano depois a mâe de Kate também morre e ela, emocionalmente abalada pelas perdas em sua vida, busca conforto junto ao médico da família, o Sr. Frederick Kolbenheyer. Ele sugeriu que ela começasse a escrever como forma de expressar sua raiva e desapontamento com a vida (SEYERSTED, 1980, p.49). Kate precisou retornar a escrever como forma de manter a si e a seus seis filhos. Na realidade, nunca conseguiu sustentar-se por meio de seus escritos, mas sustentou a família com os aluguéis de imóveis de que dispunha na Louisiana e em St. Louis.

Mulher brilhante e enérgica, cheia de alegria e carinhosa com as pessoas, ela aproveitava as festas e ocasióes sociais que passaram a fazer parte de sua vida em St. Louis, mas seus escritos revelam que sentia falta de seus queridos escritos e leituras e reclamava em ter que gastar seu tempo com homens cujo único talento eram os próprios pés.

Kate Chopin admirava profundamente o escritor francês Guy de Maupassant como alguém que olhava para dentro de si mesmo e além da vida através do seu próprio ser e escrevia, principalmente sobre solidăo, suicídio e sexo. Mesmo que ela năo tenha imediatamente tido sucesso seguindo o caminho de Guy, seus constantes esforços em uma curta mas prolífica carreira ocorriam no sentido de olhar diretamente aos leitores e contar-lhes o que via. Suas histórias começaram a aparecer em importantes revistas da época como Atlantic, Century, e Vogue.

Amor e paixăo, casamento e independência, liberdade e repressăo foram os principais temas de seu trabalho. Quando Edna Pontellier, a heroína de O Despertar, anuncia que abriria mâo do que năo é essencial; daria seu dinheiro, daria sua vida por seus filhos, mas năo a si mesma, estava levantando a questáo crucial para muitas das mulheres de Kate: a liberdade.

"Livre! Livre! Livre!", é o choro de Louise Mallard em História de Uma Hora (2011) quando ela percebe as implicaçôes da morte repentina de seu marido. Seus amigos tentaram dar-lhe a notícia de forma muito cuidadosa, pois Louise tinha um coraçăo frágil, mas sozinha em seu quarto ela vê um futuro no qual ela será livre - de corpo e alma. 
Chopin escreveu por muitos anos e sua popularidade era extrema até os críticos desaprovarem seu romance, O Despertar. Quando publicou O Despertar em 1899, Kate chocou seu público com uma representaçăo franca do despertar, social, sexual e espiritual de uma mulher.

Por contar uma história sem julgamentos ou censuras, teve a desaprovaçấo na receptividade do seu público e anuviou o final de uma carreira que trouxe para um vasto público o crescimento de uma naçâo que até entâo năo era familiar para muitos americanos. A Louisiana, com seus acadian ${ }^{4}$ e creoles, ${ }^{5}$ com seus escravos livres, com seus pântanos e cercados, era parte do continente, parte da cultura do sul. Durante um pouco mais de uma década Kate Chopin publicou em revistas nacionais e regionais duas coleçôes de contos sobre Nova Orleans e o interior de Cane River, onde ela passou doze anos de seu casamento.

Em 1899 a naçăo já tinha visto vastas mudanças na maneira de ser e agir dos americanos. Mas a ideia de uma verdadeira autonomia para as mulheres ou, mais impactante ainda, uma que se entrega aos próprios desejos de emancipaçâo era excessivamente imoral para sociedade da época. A apresentaçăo do despertar da heroína de Kate Chopin, Edna Pontellier, e seu reconhecimento indubitável por parte de mulheres respeitáveis, de fato provou que sentimentos sexuais eram fortes demais para os leitores e críticos do século XIX.

\section{KATE CHOPIN E 0 FEMINISMO}

A combinaçăo única de desejo e liberdade que tanto provocou a ira dos leitores de 0 Despertar, condenado de forma tăo intensa que quase fez com que Chopin abandonasse a carreira de escritora. Se Chopin năo tivesse mantido o tom de seus objetivos, nâo tivesse levado a seus leitores a entrega de Edna Pontellier, tivesse condenado-a com sermóes e seu próprio dedo apontado, talvez a resposta tivesse sido diferente.

Em um período em que o despertar das necessidades das mulheres era muito lento quanto à educaçăo, voto, direitos, bens móveis e direitos sobre os próprios filhos, Chopin atreveu-se a escrever sobre a luta da mulher por sua identidade. Casamento era a meta da maioria das mulheres, e isso incluía servir seus maridos e seus filhos e cumprir obrigaçōes passivamente e de forma submissa, ser solidária as suas práticas diárias, sacrificar-se por necessidade. Mulheres que aceitam esse mundo também aparecem em alguns trabalhos de Chopin como mulheres que nunca buscam por mais independência e viviam muito bem como propriedades dos seus maridos. Mas sâo as mulheres que procuram a sua própria direçăo e optam por liberdade que ganham maior destaque em suas obras.

Chopin era uma mulher que levava as mulheres extremamente a sério. Ela nunca teve dúvida quanto à habilidade das mulheres de serem fortes. Ela veio de uma descendência de mulheres fortes - sua bisavó, a avó e sua mâe - as quais ela amava e respeitava. Ela tinha muitas mulheres fortes como amigas incluindo mulheres intelectuais. Ela

Descendentes dos colonizadores franceses no Canadá.

Descendentes dos colonizadores franceses e espanhóis na América. 
via a liberdade muito mais como uma questăo de espírito e da alma. Nâo há indicaçóes de que, por exemplo, ela arrependia-se de seu casamento, ou lastimava a maternidade. Qualquer um pode inquietar-se com responsabilidades específicas e querer mais tempo para o seu trabalho ou para si mesmo. A sua liberdade era explorar ideias e escrever sobre o que lhe tocava a alma. Chopin era uma dedicada e talentosa escritora, que trabalhava duramente para capturar sentimentos em prosa.

\subsection{Relato e crítica de $O$ Despertar}

O Despertar, de Kate Chopin, é um romance sobre o "despertar" de uma mulher em todos os sentidos. No decorrer do romance a protagonista, Edna Pontellier, começa a descobrir que ela pode ser o que quiser. Por amor, ela esquece as regras sociais, o que era muito difícil para uma mulher que vivia na Nova Orleans do século dezenove, em um período em que as mulheres tinham poucos direitos.

A publicaçăo de $O$ Despertar, em 1899, foi um autêntico escândalo. E embora a "new woman" do final do século XIX que exigia igualdade social, econômica e política já fosse um tema corrente nas discussōes e na ficçâo da época, o retrato de uma mulher tăo sensual como Edna Pontellier era mais do que os críticos podiam permitir passar. 0 Despertar foi descrito como trivial e sórdido, essencialmente vulgar e de sentimentos mórbidos. Chopin se sentiu ferida por estas críticas e pelo ostracismo social que lhe acarretaram, e náo voltou a publicar nenhuma outra novela: a autora havia sido castigada pelo comportamento de sua heroína.

Mas, enquanto muitos leitores têm visto o muito debatido suicídio de Edna Pontellier como o castigo pela transgressăo feminina contra a moralidade, as mais recentes leituras feministas o consideram um abraço heróico e transcendentalista com a independência, e uma simbólica ressurreiçăo. A partir dos anos 70, Edna passou a ser lida náo como uma mulher egoísta e imoral, mas sim como uma pessoa imersa em um momento histórico específico, em que era impensável que uma mulher abdicaria de suas responsabilidades domésticas em favor de suas próprias aspiraçóes e necessidades. A crítica feminista vê esta conclusâo como uma forma de escapar do clichê segundo o qual as mulheres que transgrediam as normas sociais deviam ser castigadas a morte. Assim lido, o final seria uma experiência transcendente em que Edna alcança a reconciliaçấo consigo mesma, e nâo como o poder da sociedade contra a rebeldia feminina.

Edna representa as necessidades humanas de descobrir e realizar seus desejos individuais, de arriscar, de tentar, de agir, dentro de uma sociedade que encoraja a conformidade.

$\mathrm{O}$ que estou fazendo aqui? Essa talvez era a pergunta inquietante que martelava a cabeça de Edna. Ela era infeliz mas, para as pessoas que a rodeavam e para a sociedade em que ela estava inserida, com certeza a pergunta seria outra: o que ela poderia querer mais?

Dinheiro, marido, filhos, status social. É simples resumirmos a vida de uma pessoa e achar que ela nâo pode querer mais. Mas, sim, Edna queria mais. Queria nâo ter nenhuma condescendência com o tédio, năo ser forçada a aceitá-lo na sua rotina como um inquilino inevitável. Queria que sua vida, até entăo sensata, năo lhe roubasse o direito ao desatino. Ela nâo aceitava a ideia de que a maturidade exige um certo conformismo. E ela năo teve medo e nem vergonha de desejar. 
Ela queria sensaçōes inéditas e assim foi até o fim dos seus dias. Ela optou por năo morrer um pouquinho a cada dia, sufocada em obrigaçôes e em exigências de ser a melhor máe do mundo, a melhor esposa do mundo, a melhor qualquer coisa.

Kate Chopin sintetiza a sua obra e reafirma os seus próprios ideais ao dizer que talvez seja melhor acordar depois de tudo, mesmo para sofrer, do que permanecer enganado por ilusóes durante toda a vida.

Banido ou nâo, O Despertar desapareceu das vistas do público e Chopin era vagamente lembrada como uma talentosa colorista local. Sua obra mereceu apenas pequenas mençôes da história na literatura até os anos cinquenta, quando as críticas dos Estados Unidos e da França reconheceram seu talento e reviveram o interesse por seus trabalhos.

A nova geraçấo, sensível às necessidades das mulheres, começou a aceitar a sexualidade das mesmas e apreciaram o livro. Agora, O Despertar aparece na lista de leitura das universidades e já inspirou filmes. Mais de um século depois, a América despertou para o romance de Kate Chopin e finalmente destinou o respeito para uma mulher que estava à frente do seu tempo.

\section{CONSIDERAÇÕES FINAIS}

Uma teoria feminista ideal sustentaria um pensamento que procurasse desfazer confusôes a respeito do corpo, do sexo e das diferenças sexuais e das relaçôes de poder entre homens e mulheres. Neste sentido nota-se um grande avanço do feminismo no que tange à ideologia sexista; pouco se fala, porém, na significaçăo do "ser mulher" ou da subjetividade individual. A mulher passa, assim, a ser concebida como algo além de um gênero, simplesmente, sendo encarada também como um ser humano completamente embodied, que năo pode ser reduzido à diferença sexual, quer seja esta diferença vista como algo natural, quer seja entendida como efeito cultural. Ser mulher é romper os limites do que é determinado biologicamente, buscar a emancipaçâo espiritual e sexual e despertar a consciência da condiçâo de ser enquanto pessoa, com sonhos e ideais.

Juana Inés de la Cruz e Kate Chopin contribuíram de forma valiosa para o destacamento do papel da mulher dentro das sociedades machistas. Construíram uma compreensâo histórica do que significa ser mulher ou homem em determinada sociedade, remetendo a um feminismo engajado na busca pela justiça e igualdade entre os sexos.

A igualdade de gêneros ainda está longe de acontecer, mas é através de mulheres como Juana Inés de la Cruz e Kate Chopin e sua coragem e talento literário, que a luta a favor do direito das mulheres consegue ecoar pelos quatro cantos do mundo. E podem inspirar ou ser um caminho para abrir discussóes sobre abordagens feministas através da literatura. 


\section{REFERÊNCIAS}

BLOOM, Harold, ed. Kate Chopin. Modern Critical Views. New York: Chelsea House Publischers, 1987.

CHOPIN, Kate. The awakening. New York: Dover Publications, Inc., 1993.

CHOPIN, Kate. $O$ despertar. Săo Paulo: Editora Estaçăo Liberdade, 1994.

CHOPIN, Kate. A história de uma hora. In: VIÉGAS-FARIA, Beatriz; CARDOSO, Betina Mariante; BROSE, Elizabeth (Org.) Kate Chopin: contos traduzidos e comentados Estudos literários e humanidades médicas. Porto Alegre: Casa editorial Luminara, 2011, pp. 79-82.

DYER, Joyce. The awakening: a novel of beginnings. New York: Twayne, 1993.

EMMIT, Helen V. Drowned in a willing sea: freedom and drowning in Eliot, Chopin, and Drabble. Tulsa, Ok.: Tulsa Studies in Women's Literature, v. 12, n. 2, 1993.

GILBERT, Sandra M. The second coming of aphrodite: kate chopin's fantasy of desire. New York: Penguin Books, 1983.

HORTA, Maurício. Luxúria: como ela mudou a história do mundo. Săo Paulo: LeYa, 2015. MALZAHN, Manfred. The strange demise of Edna Pontellier. Chapel Hill, C.N.: The Southern Literary Journal, v. 23, n..2, Spring 1992.

MAY, John R. Local color in the awakening. Baton Rouge, Louisiana: North Critical Edition, 1993.

ROSCHER, Marina L. The suicide of Edna Pontellier: an ambiguous ending? Southern Studies v. 23, 1984, pp. 289-298.

SEYERSTED, Per. Kate Chopin: a critical biography. Louisiana State University Press: Baton Rouge,1980.

SHOWALTER, Elaine. Sister's choice: tradition and change in american women's writing. Oxford: Claredon Press, 1991.

SKAGGS, Peggy. Three tragic figures in Kate Chopin's the awakening. Louisiana State University Press: Baton Rouge, 1970.

SPANGLER, George M. Kate chopin's the awakening: a partial dissent. A Norton Critical Edition. New York: Norton, 1976.

STANGE, Margit. Personal property: exchange value and the female self in the awakening. Boston: Donal Keesey, 1989.

TAVEIRA, Thalita Rose Tamiarana Gadêlha. Representaçôes de gênero no barroco latino-americano: Gregório de Matos e Sor Juana Inés de la Cruz. UFPB: Joăo Pessoa, 2017.

TOTH, Emily. Unveiling Kate Chopin. Jackson: University press of Mississipi, 1999.

URGO, Joseph R. A Prologue to rebellion: the awakening and the habit of self-expression. University of North Carolina: Chapel Hill, N.C.,1987. 
VANSPANCKEREN, Katheryn. Perfil da Literatura Americana. Agência de Divulgaçăo dos Estados Unidos da América, 1994.

WYATT, Neal. Biography by Kate Chopin (1995). Disponível em https://archive.vcu.edu/ english/engweb/webtexts/hour/katebio.html. Acesso em 15 de nov.2019. 